\title{
Electrochemical Study of Clean and Pre-Corroded Reinforcements Embedded in Mortar Samples with Variable Amounts of Chloride Ions
}

\author{
María de las Nieves González ${ }^{1}\left(\mathbb{D}\right.$, María Isabel Prieto $\left.{ }^{1, *} \mathbb{(}\right)$, Alfonso Cobo ${ }^{1}\left(\mathbb{D}\right.$ and Fernando Israel Olmedo ${ }^{2}$ \\ 1 Escuela Técnica Superior de Edificación, Universidad Politécnica de Madrid, Avda. Ramiro de Maeztu, 7, \\ 28040 Madrid, Spain; mariadelasnieves.gonzalez@upm.es (M.d.1.N.G.); alfonso.cobo@upm.es (A.C.) \\ 2 Valladares Ingeniería S.L, C/Julián Camarillo, 42, 28037 Madrid, Spain; fiolmedoz@gmail.com \\ * Correspondence: mariaisabel.prieto@upm.es; Tel.: +34-910-675-4341
}

Citation: González, M.d.l.N.; Prieto, M.I.; Cobo, A.; Olmedo, F.I.

Electrochemical Study of Clean and Pre-Corroded Reinforcements Embedded in Mortar Samples with Variable Amounts of Chloride Ions. Materials 2021, 14, 6883. https:// doi.org/10.3390/ma14226883

Academic Editor: Emilia Morallon

Received: 2 October 2021

Accepted: 12 November 2021

Published: 15 November 2021

Publisher's Note: MDPI stays neutral with regard to jurisdictional claims in published maps and institutional affiliations.

Copyright: (c) 2021 by the authors. Licensee MDPI, Basel, Switzerland. This article is an open access article distributed under the terms and conditions of the Creative Commons Attribution (CC BY) license (https:// creativecommons.org/licenses/by/ $4.0 /)$.

\begin{abstract}
The present study investigates the possibility of re-surfacing previously corroded reinforcements and the suitability of the two electrochemical techniques that are widely used to determine the state of corrosion of steel (the corrosion potential $\mathrm{E}_{\mathrm{corr}}$ and the corrosion rate $\mathrm{i}_{\text {corr }}$ ). In order to test this, 32 pre-corroded B500SD reinforcing steel bars have been used for one year, where half of the bars have been cleaned to eliminate corrosion products. The other half have been maintained with the generated corrosion products. Subsequently, the bars have been embedded in cement mortar samples with variable amounts of chloride ion, and $\mathrm{E}_{\text {corr }}$ and $\mathrm{i}_{\text {corr }}$ have been measured for 250 days. The results showed that it is not possible to rework the reinforcement without removing corrosion products and that it is not possible to predict the passive or active state of steel by measuring $\mathrm{E}_{\mathrm{corr}}$ only.
\end{abstract}

Keywords: repassivation; corrosion; reinforcement; electrochemical techniques

\section{Introduction}

Reinforcement corrosion is accepted as the main cause of the reduction in the service life of reinforced concrete structures (RCSs) [1-3]. The enormous economic impact of this problem, due to the direct and indirect costs involved, has led to a vast development of new technologies and materials with the purpose of increasing the durability of RCSs [4-7]. In the USA, direct costs due to corrosion of RCSs infrastructure are estimated at $0.25 \%$ of GNP, which corresponds to USD 16.6 billion per year [8].

The steel reinforcements embedded in the RCS are in a passive state that are protected against corrosion. This protection is due to the existence of a passive layer formed at the steel/concrete interface, which is self-healing and very thin around $10 \mathrm{~nm}$ [9]. Its formation and stability are guaranteed by the high alkalinity of the concrete, usually between the range of $\mathrm{pH} 13-14$, and by the existence of an appropriate electrochemical potential [10].

The loss of the passivity of the RCS reinforcement is due, in most cases, to the following factors: the presence of despassivating ions, essentially chlorides, in sufficient quantity to locally break up the passivating layers [11]; or the decrease in the $\mathrm{pH}$ of the concrete, due to the effect of the $\mathrm{CO}_{2}$ present in the atmosphere [12-14]. In addition to the triggering factor that induces corrosion, the environment in which the structure is located determines the variables that most significantly influence its behavior. In the case of marine environments, the chloride diffusion coefficient, the concentration of chlorides on the surface and the thickness of the rebar coating are the most determining parameters to be able to evaluate its behavior, while in the case of underground tunnels, although corrosion is induced by chlorides, the formation of $\mathrm{NaCl}$ crystals is a parameter to take into account [15,16].

For decades, numerous investigations have been carried out to explain the role of the factors that trigger corrosion of rebars, especially chloride ions $[17,18]$, whose mechanism can be seen in the Figure 1. 

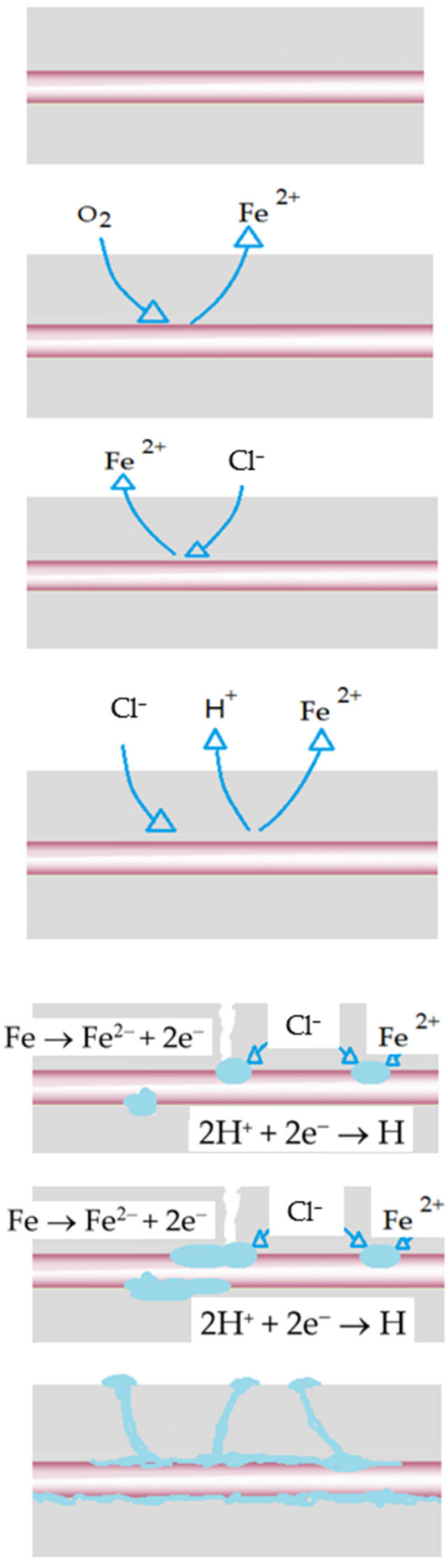

The steel-concrete system does not contain $\mathrm{Cl}^{-}$

Passive state with unlimited durability<smiles></smiles>

Electrolyte + gaps + oxygen

Differential aeration stacks<smiles></smiles>

Gradual enrichment of gaps with $\mathrm{Fe}^{2+}$ and $\mathrm{Cl}^{-}$ Differential concentration stacks

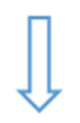

Acid hydrolysis $\mathrm{Fe}^{2+}+\mathrm{Cl}^{-}+\mathrm{H}_{2} \mathrm{O}=\mathrm{Fe}(\mathrm{OH})_{2}+2 \mathrm{H}^{+}$ Differential $\mathrm{pH}$ stacks

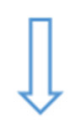

Local break of passivity Active / passive stacks<smiles>CCCCCCC</smiles>

Corroded and non-corroded steel areas<smiles>CCCCCCC</smiles>

General corrosion and overlapping pitting Durability limited by corrosion of steel

Figure 1. Chloride corrosion mechanism in reinforced concrete structures.

The critical threshold of chloride ions $\left(\mathrm{C}_{\text {crit }}\right)$ needed to despassivate the steel is one of the critical parameters in the prediction and evaluation of corrosion [17]. The knowledge of $C_{\text {crit }}$ is fundamental when establishing the requirements to achieve structures with sufficient durability and to evaluate the service life or residual life of existing structures [18]. The onset of corrosion due to the effect of chlorides in the concrete reinforcements has been related to an increase in the ratio $\left[\mathrm{Cl}^{-}\right] /\left[\mathrm{OH}^{-}\right]$above a certain value, which was initially set by Haussman at 0.6 [19-24]. However, it was later found that it can be affected by other parameters such as the amount of air retained in the holes of the steel-concrete interface or the presence of defects [23,25-30]. Numerous studies depict that there is a significant 
dispersion in $\mathrm{C}_{\text {crit }}$ values. In most cases, the limits are set in relation to the weight of the cement: For example, for concrete with a water/cement ratio of 0.5 mainly located in marine environments in the intertidal zone in Europe with a limit value of $0.5 \%$ suggested [31]. In Spain, the mandatory regulations establish a durability strategy based on the service life of the structure, but always with a limit of $\mathrm{Cl}^{-}$of $0.4 \%$ [32]. In the United States, the thresholds are set according to the exposure class of the structure, ranging from $0.15 \%$ to $0.30 \%$, and may reach $1 \%$ for structures located in dry environments [33]. At present, there are numerous investigations that model the corrosion behavior of the reinforcements embedded in the reinforced concrete and the influence of the concrete quality, the concentration of chlorides and the coating and the cracking, on the rate of corrosion, under different environmental conditions [34-37]. In addition, these investigations, validated on the corresponding experimental works, have allowed to simulate the influence that the size of the pits have on the geometry of the fissures and how the accumulation of oxide in the pits influence the adhesion between concrete and steel [38].

The realization of potential maps according to ASTM C876-09 [39] is the electrochemical technique most commonly used to diagnose the risk of corrosion in RCSs [2,40]. However, the results of the evaluation of RCSs with corroded reinforcements may indicate different degrees of corrosion or probability of corrosion depending on the technique used for corrosion assessment [41,42]. It is generally accepted that the measurements of corrosion potential $\left(\mathrm{E}_{\mathrm{corr}}\right)$ should be completed with other procedures $[40,43]$. The measurement of corrosion rate is a quantitative technique that is known for decades [44]. However there have been found large variations in the values of corrosion rate for narrow ranges of values of corrosion potential [45].

Taking into account the previous premises, the aims of the work are to verify the possibility of re-surfacing previously corroded reinforcements and to verify the suitability of two electrochemical techniques widely used to determine the corrosion status of reinforcement by correlating the $\mathrm{E}_{\text {corr }}$ and the $\mathrm{i}_{\text {corr }}$ measurements.

\section{Experimental Program}

In this study, two issues related to corrosion of RCS reinforcements have been investigated: (i) The possibility of re-surfacing previously corroded reinforcements and (ii) the verification of the suitability of two electrochemical techniques widely used to determine the corrosion status of reinforcements. In order to test this, 32 B500SD reinforcing steel bars of $6 \mathrm{~mm}$ diameter and $120 \mathrm{~mm}$ length have been used. The chemical composition of the steel is shown in Table 1. The analyses have been carried out with an Optical Emission Spectrometer by Arc/Spark model SPECTROMAX.

Table 1. Chemical composition of the steel used.

\begin{tabular}{cccccccccc}
\hline Element & $\mathbf{C}$ & $\mathbf{S i}$ & $\mathbf{M n}$ & $\mathbf{P}$ & $\mathbf{S}$ & $\mathbf{C r}$ & $\mathbf{N i}$ & $\mathbf{C u}$ & $\mathbf{M o}$ \\
\hline Composition $(\%)$ & 0.21 & 0.22 & 0.72 & $<0.01$ & 0.022 & 0.05 & 0.09 & 0.08 & $<0.05$ \\
\hline
\end{tabular}

The rebars have been embedded in cement mortar samples of $80 \times 55 \times 20 \mathrm{~mm}^{3}$ with a cement/sand/water dosage of $1 / 3 / 0.5$. CEM I 42.5R Portland cement according to RC-16 standard [46], siliceous sand with a maximum size of $0.4 \mathrm{~mm}$ and drinking water supplied by Canal de Isabel II in Madrid were used. The physical characteristics and chemical composition of the cement and the sand used can be seen in Table 2 . 
Table 2. Physical characteristics and chemical composition of cement and sand.

\begin{tabular}{|c|c|c|c|c|}
\hline & \multicolumn{2}{|c|}{ Physical Characteristics } & \multicolumn{2}{|c|}{ Chemical Composition } \\
\hline \multirow{4}{*}{ Cement } & Blaine specific surface area & $414 \mathrm{~m}^{2} / \mathrm{kg}$ & $\mathrm{SO}_{3}$ & $3.40 \%$ \\
\hline & Density & $3.15 \mathrm{~g} / \mathrm{cm}^{3}$ & $\mathrm{Cl}^{-}$ & $0.01 \%$ \\
\hline & Initial setting time & $108 \mathrm{~min}$ & Calcination loss & $1.72 \%$ \\
\hline & Final setting time & $160 \mathrm{~min}$ & Insoluble residue & $0.40 \%$ \\
\hline \multirow{7}{*}{ Sand } & Sand equivalent & 78 & $\begin{array}{l}\mathrm{S}, \mathrm{SO}_{3}, \mathrm{Cl}^{-} \text {and } \\
\text { low specific }\end{array}$ & \\
\hline & Real density & $2.619 \mathrm{~g} / \mathrm{cm}^{3}$ & weight particles & $0.00 \%$ \\
\hline & $\begin{array}{l}\text { Normal absorption } \\
\text { coefficient }\end{array}$ & $15 \%$ & Fine & $0.78 \%$ \\
\hline & $\begin{array}{l}\text { Saturated surface } \\
\text { dry density }\end{array}$ & $2.630 \mathrm{~g} / \mathrm{cm}^{3}$ & & \\
\hline & Clay clumps & $0.01 \%$ & & \\
\hline & $\begin{array}{l}\text { Coefficient of type of } \\
\text { course aggregate }\end{array}$ & $0.26 \%$ & & \\
\hline & Soft particles & $0.93 \%$ & & \\
\hline
\end{tabular}

The steel rebars were embedded in the specimens, leaving $5 \mathrm{~cm}$ outside, in which the risk of differential aeration at the triple atmosphere/mortar/steel interface was eliminated by means of adhesive tape. The specimens were demolded after $24 \mathrm{~h}$ and cured in a wet chamber for 28 days at a temperature of $20 \pm 2{ }^{\circ} \mathrm{C}$ and a humidity above $90 \%$. Subsequently, they were subjected to a constant anodic polarization of $20 \mu \mathrm{A} / \mathrm{cm}^{2}$ during one year. In the photograph (Figure 2a), one of the specimens can be seen after the passage of the electric current. The samples were mixed with an addition of $2 \%$ of $\mathrm{Cl}^{-}$in relation to the weight of the cement to ensure that the anodic polarization would lead to corrosion of the reinforcements and would not cause the electrolysis of the water in the pore network.
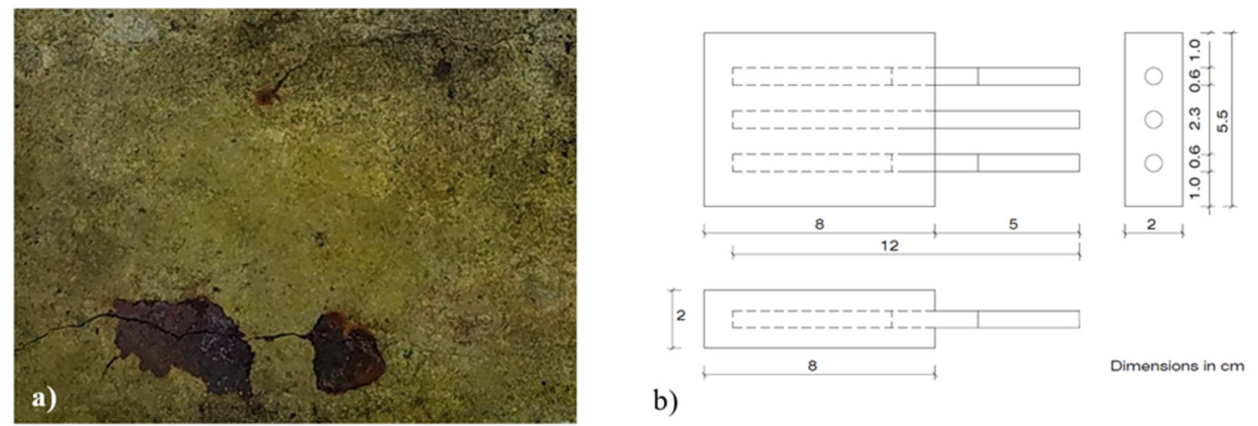

Figure 2. Specimens used in the study of corrosion. (a) Symptoms in pre-corroded specimens (first phase); (b) Scheme of the specimens with variable amounts of chloride ion (second phase).

Once the pre-corrosion of the rebars was complete, the mortar samples were then broken and the rebars removed. Half of the rebars (16 pieces) were chosen at random, and the corrosion products were completely removed by dissolving the iron oxides and hydroxides in $50 \% \mathrm{HCl}$ inhibited with $4 \mathrm{~g} / 1$ urotropin (hexamethylenetetramine). With the clean rebars (CLN), 8 specimens similar to those of the first phase were performed, but with variable amounts of chloride ion of $0.0 \% ; 0.2 \% ; 0.4 \% ; 0.6 \% ; 0.8 \% ; 1.0 \% ; 1.5 \%$; and $2.0 \%$ in relation to the weight of cement and with the incorporation of a third rebar located in the center to facilitate the electrochemical measurements (Figure 2b). The same process has been carried out with the rebars that hold the corrosion products. Then the 16 specimens were kept in a wet chamber for 250 days at a temperature of $20 \pm 2{ }^{\circ} \mathrm{C}$ and a humidity above $90 \%$. During this time the corrosion potential $\left(\mathrm{E}_{\text {corr }}\right)$, and corrosion rate were periodically recorded using an AUTOLAB/PGSTAT302N potentiostat in which the outer bars were used as working electrodes and the central bar as an auxiliary electrode 
(Figure 3). The reference electrode used was $\mathrm{Cu} / \mathrm{CuSO}_{4}$. The corrosion rate was measured by the corrosion current density $\left(\mathrm{i}_{\text {corr }}\right)$ obtained by measuring the polarization resistance $\left(R_{p}\right)$ by the Stern and Geary equation [47]:

$$
\mathrm{i}_{\text {corr }}=\frac{\mathrm{B}}{\mathrm{R}_{\mathrm{p}}}
$$

where the value of $26 \mathrm{mV}$ for the constant $B$ was chosen [48]. The value of $R_{p}$ was obtained by applying polarization of $10 \mathrm{mV}$ and measuring the current response after $15 \mathrm{~s}$. The reference values for predicting the corrosion state as a function of $\mathrm{E}_{\mathrm{corr}}$ and $\mathrm{i}_{\mathrm{corr}}$ are shown in Table $3[39,49]$.

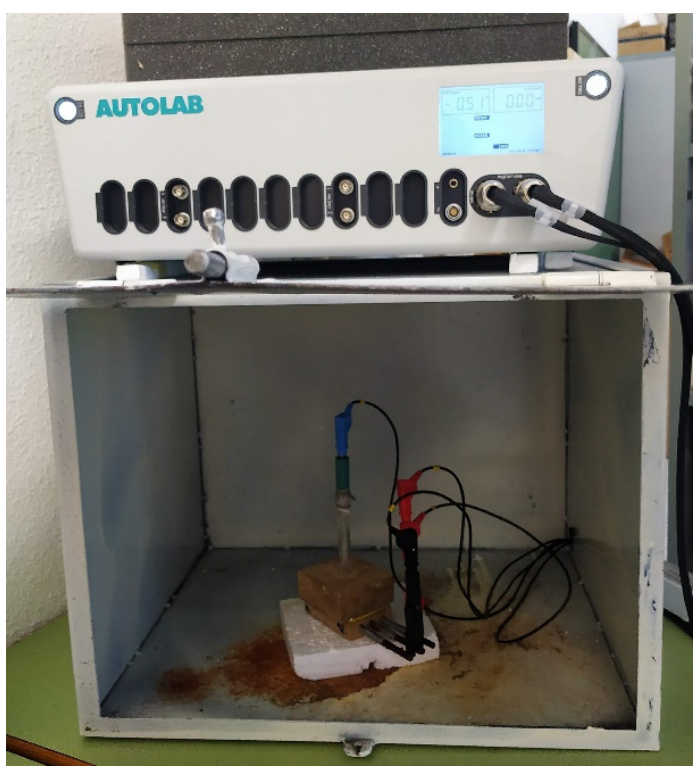

Figure 3. Performing electrochemical measurements.

Table 3. Reference values for $\mathrm{E}_{\text {corr }}$ and $\mathrm{i}_{\text {corr }}$.

\begin{tabular}{ccc}
\hline Measurement & Risk & Values \\
\hline \multirow{2}{*}{$\mathrm{E}_{\text {corr }}(\mathrm{mV})$} & High $>90 \%$ & $\mathrm{E}_{\text {corr }}<-350$ \\
& Uncertainty & $-350<\mathrm{E}_{\text {corr }}<-200$ \\
& Low $<10 \%$ & $\mathrm{E}_{\text {corr }}>-200$ \\
\hline & Active state & $\mathrm{i}_{\text {corr }}>1 \mu \mathrm{A} / \mathrm{cm}^{2}$ \\
& High corrosion & $0.5 \mu \mathrm{cm} / \mathrm{cm}^{2}<\mathrm{i}_{\text {corr }}<1 \mu \mathrm{A} / \mathrm{cm}^{2}$ \\
$\mathrm{i}_{\text {corr }}\left(\mu \mathrm{A} / \mathrm{cm}^{2}\right)$ & Low corrosion & $0.1 \mu \mathrm{A} / \mathrm{cm}^{2}<\mathrm{i}_{\text {corr }}<0.5 \mu \mathrm{A} / \mathrm{cm}^{2}$ \\
& Passive state & $\mathrm{i}_{\text {corr }}<0.1 \mu \mathrm{A} / \mathrm{cm}^{2}$ \\
\hline
\end{tabular}

With respect to the thresholds of the $\mathrm{E}_{\text {corr }}$ value there is a very broad consensus throughout the scientific and technical community, most likely due to the enormous diffusion at the international level of the ASTM C 876-09 standard. Regarding $i_{\text {corr }}$ thresholds, it is widely accepted that $\mathrm{i}_{\text {corr }}<0.1 \mu \mathrm{A} / \mathrm{cm}^{2}$ corresponds to steel in a passive state, and above this value steel corrodes and $\mathrm{i}_{\text {corr }}>1 \mu \mathrm{A} / \mathrm{cm}^{2}$ is very dangerous [42,44,50-53].

\section{Results and Discussion}

Figure 4 shows the evolution in time of the $i_{\text {corr }}$ of all the analyzed rebars. Each of the data have been obtained as the arithmetic mean of the two rebars in the same state and embedded in the same specimen. The abbreviation CLN indicates that the rebar has been cleaned while the abbreviation COR indicates that the rebar keeps the corrosion products. The final numbers indicate the amount of $\mathrm{Cl}^{-}$, expressed as a percentage by weight of cement, present in the specimens. It can be seen that, in most cases, the starting point is an 
$\mathrm{i}_{\text {corr }}$ that decreases in a very similar way during the first 35 days of exposure. After this period of exposure, the $i_{\text {corr }}$ remains at very stable values most probably because of the humidity of the environment remaining constant. Figure 5 shows the values corresponding to the $\mathrm{i}_{\text {corr }}$ of all the rebars after 250 days.

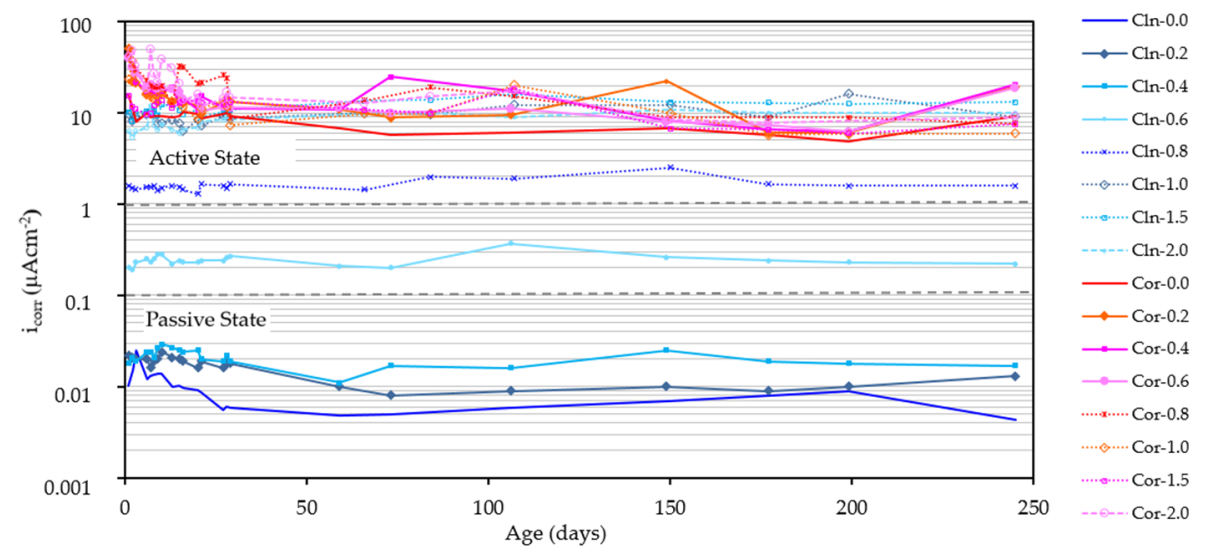

Figure 4. Evolution of $\mathrm{i}_{\text {corr }}$ over time for all the rebars studied.

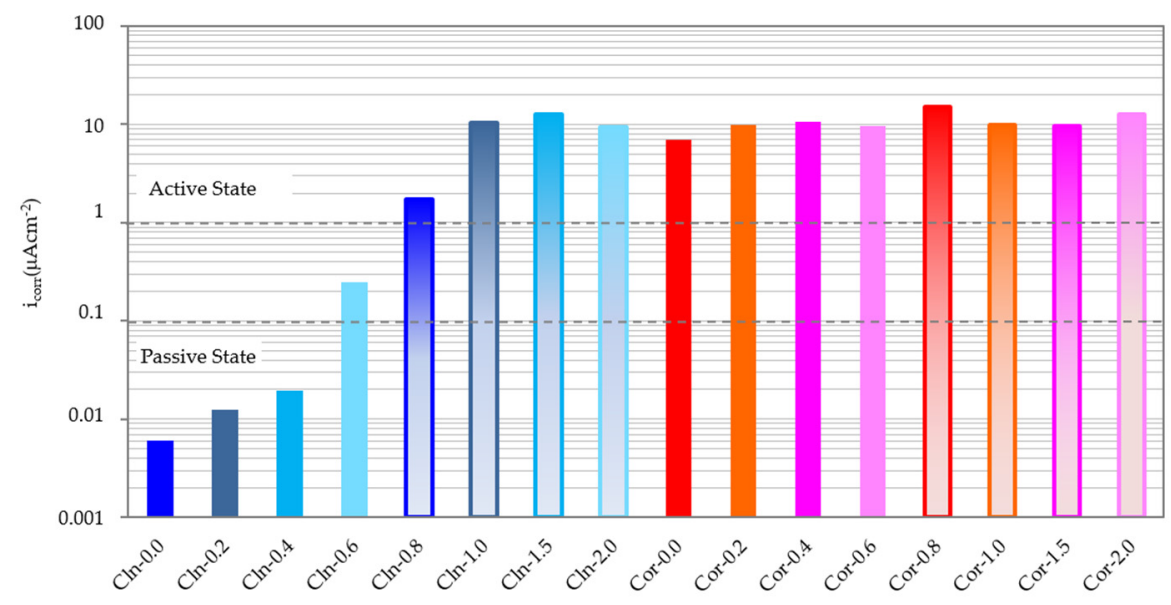

Figure 5. $i_{\text {corr }}$ measurement of all rebars after 250 days.

If the clean rebars (CLN) are analyzed, the analysis depicted in Figures 4 and 5 indicate that only the rebars embedded in mortar samples of up to $0.4 \%$ of $\mathrm{Cl}^{-}$in weight of cement are kept in a passive state. These results are in agreement with the indications of the EHE and ACI $[32,33,54]$. The embedded rebars in specimens with $0.6 \% \mathrm{Cl}^{-}$are maintained with low corrosion levels. Rebars in specimens with $0.8 \% \mathrm{Cl}^{-}$are maintained with $\mathrm{i}_{\text {corr }}$ between 1 and $2 \mu \mathrm{A} / \mathrm{cm}^{2}$. With higher amounts of $\mathrm{Cl}^{-}$, the rebars maintain $\mathrm{i}_{\text {corr }}$ at approximately $10 \mu \mathrm{A} / \mathrm{cm}^{2}$. Similar results were obtained in previous investigations, observing that a greater amount of chloride ion present in the mortar, generates a higher rate of corrosion in the rebars $[49,55,56]$.

All the rebars that have kept the corrosion products (COR) exhibit very high $\mathrm{i}_{\text {corr }}$ values $\left(10 \mu \mathrm{A} / \mathrm{cm}^{2}\right)$ regardless of the amount of $\mathrm{Cl}^{-}$present in the mortar. Moreover, the $i_{\text {corr }}$ of the bars does not depend on the amount of chloride ion, which proves the impossibility of reworking reinforcements with thick corrosion products when these are not eliminated. This is because the $i_{\text {corr }}$ in the reinforcements that corrode in an active state are sufficient to maintain an acid $\mathrm{pH}$ in the steel/corrosion products interface within such an alkaline medium as concrete, so that, once corrosion has been triggered, $\mathrm{Cl}^{-}$are not necessary to maintain it $[49,55,57]$. Similar results were obtained by Miranda et al., when they observed that the higher the degree of pre-corrosion of the steel, the higher its corrosion rate, even in chloride-free environments [56,57]. 
The evolution of the $\mathrm{E}_{\mathrm{corr}}$ in the same period of time can be seen in Figure 6. Figure 7 depicts in more detail the $\mathrm{E}_{\mathrm{corr}}$ values reached by all the bars after 250 days.

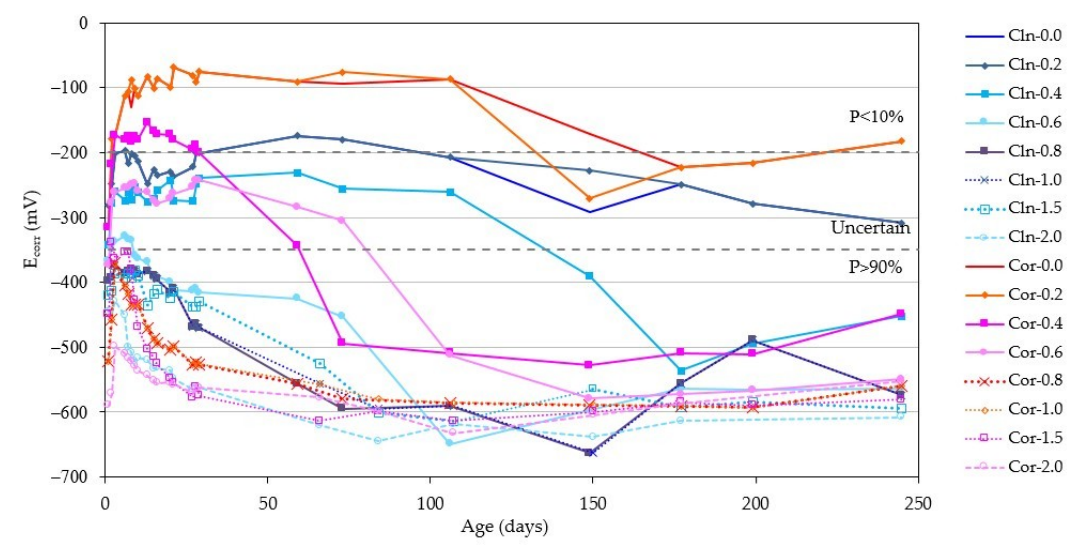

Figure 6. Evolution of the $\mathrm{E}_{\mathrm{corr}}$ over time for all the rebars studied.

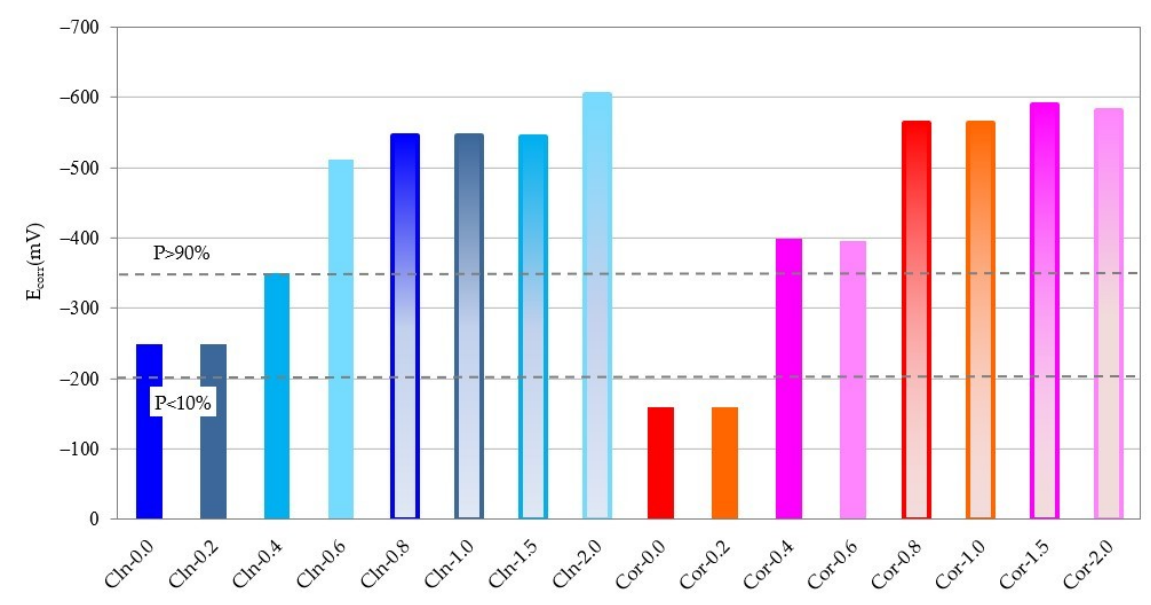

Figure 7. Measurement of the $\mathrm{E}_{\text {corr }}$ of all rebars after 250 days.

If we compare the evolution in time of the graphs in Figures 4 and 6, we can see that the $\mathrm{E}_{\mathrm{corr}}$ suffers a greater variation than the $\mathrm{i}_{\text {corr }}$, reaching, in some cases (corroded rebar introduced in a specimen with $0.4 \%$ of $\mathrm{Cl}^{-}$), values, during the whole studied period, typical of the passive, uncertain and active state, since the measurement of the potential for corrosion varies enormously depending on various factors, such as temperature and humidity [58]. It can also be seen that at 250 days, the $\mathrm{E}_{\mathrm{corr}}$ value depends much more on the amount of $\mathrm{Cl}^{-}$in the specimen than on the passive or active state of the rebar, so that the $\mathrm{E}_{\text {corr }}$ of rebars in specimens containing the same amount of $\mathrm{Cl}^{-}$are very similar, regardless of whether the rebar has been embedded in the clean specimen or with the corrosion products (Figures 6 and 7).

If the values of $E_{\text {corr }}$ and $i_{\text {corr }}$ are represented in a system of axes together with the thresholds that delimit the passive and active states, it is possible to check the validity of the $\mathrm{E}_{\mathrm{corr}}$ measurements as a predictor of the corrosion state of a rebar (Table 3). Choosing as ordinate axis the value of $\mathrm{E}_{\mathrm{corr}}$ and as $x$-axis the value of $\mathrm{i}_{\text {corr }}$ and marking by vertical and horizontal lines the thresholds of these values, the space is divided into 6 quadrants (Figure 8). 


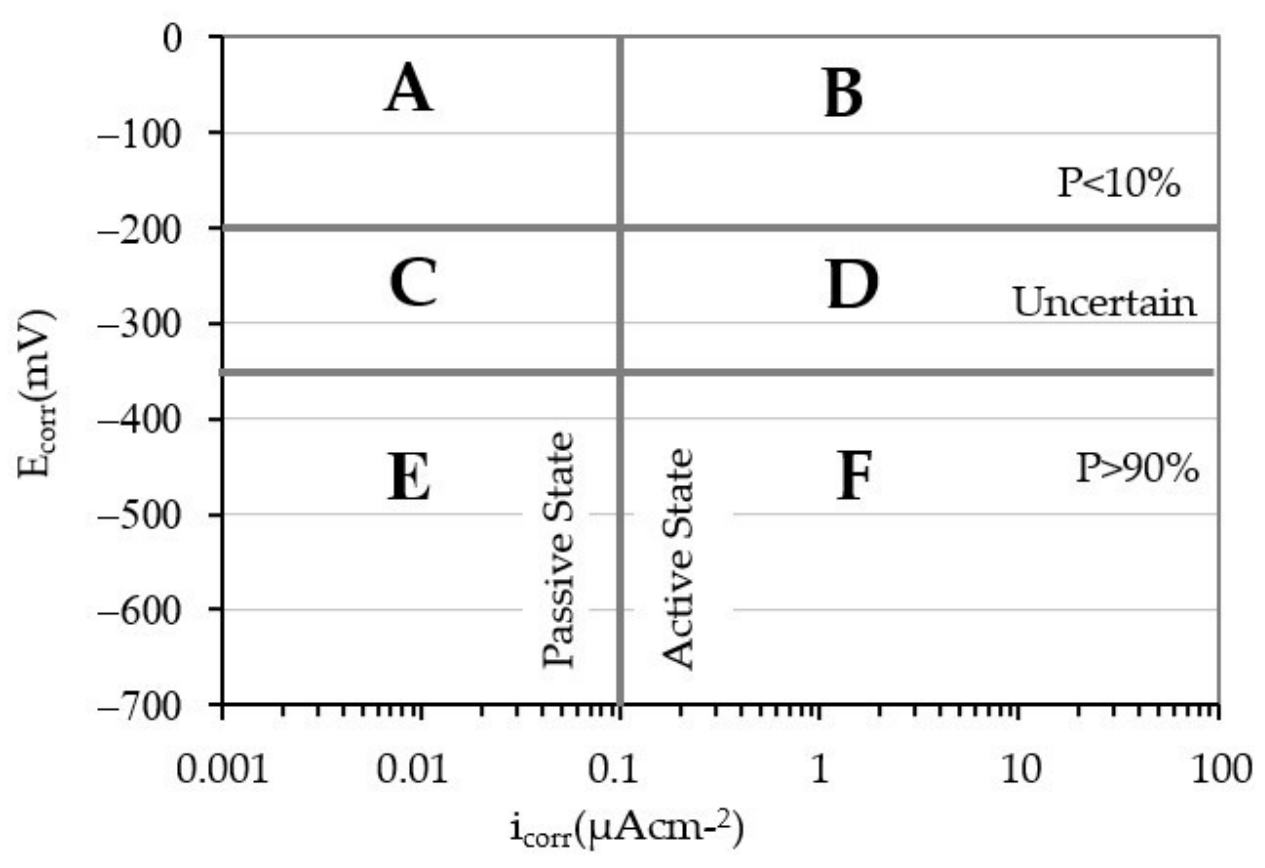

Figure 8. Joint representation of $\mathrm{E}_{\mathrm{corr}}$ and $\mathrm{i}_{\mathrm{corr}}$ in the plane.

In quadrants $\mathrm{A}$ and $\mathrm{F}$, corrosion states coincide that predict the measurements of the $\mathrm{E}_{\text {corr }}$ and $\mathrm{i}_{\text {corr }}$ : Quadrant A corresponds to measurements that indicate the passive state while the measurements of quadrant $F$ indicate the active state. In contrast, quadrants $B$ and $\mathrm{E}$ define corrosion states with total discrepancy between the prediction of the $\mathrm{E}_{\mathrm{corr}}$ and $\mathrm{i}_{\text {corr. }}$ Quadrants $C$ and $D$ define corrosion states where the $E_{\text {corr }}$ predicts an uncertain state.

Figure 9 depicts the $E_{\text {corr }}$ and $i_{\text {corr }}$ values for each of the specimens obtained in all measurements. The graphs on the left column correspond to the clean rebars (CLN) while the right column corresponds to the values of the rebars with corrosion products (COR). In the two graphs located in the same row, the amount of $\mathrm{Cl}^{-}$present in the test pieces coincides. Figure 10 shows the values of all the rebars together.

The analysis of all the graphs in Figure 9, shows that only the predictions of the $\mathrm{E}_{\mathrm{corr}}$ and $\mathrm{i}_{\text {corr }}$ for rebars with an ongoing corrosion process and containing at least $0.8 \%$ $\mathrm{Cl}^{-}$coincide. In these cases, all the data points of the graphs are located in quadrant $\mathrm{F}$ indicated in Figure 8, regardless of whether the rebars are clean or with corrosion products. In addition, the $\mathrm{E}_{\text {corr }}$ value becomes more electronegative as the amount of $\mathrm{Cl}^{-}$present in the specimen increases and regardless of the state of the rebar. This trend is more pronounced for very low amounts of $\mathrm{Cl}^{-}$and does not depend on the corrosion state of the reinforcement.

The analysis in Figure 10 allows verification of (i) the rebars in passive state ( $\mathrm{i}_{\text {corr }}<0.1 \mu \mathrm{A} / \mathrm{cm}^{2}$ ) show a large number of $\mathrm{E}_{\text {corr }}$ values corresponding to high probabilities of corrosion (quadrant $\mathrm{A}$ ) or uncertain states (quadrant $\mathrm{C}$ ), and (ii) the rebars in active state $\left(i_{\text {corr }}>0.1 \mu \mathrm{A} / \mathrm{cm}^{2}\right)$ that show a large number of $E_{\text {corr }}$ values corresponding to low probabilities of corrosion (quadrant F) or uncertain states (quadrant D). These results show the impossibility of predicting the passive or active state of the steel only by means of $\mathrm{E}_{\text {corr }}$ measurements [58]. 

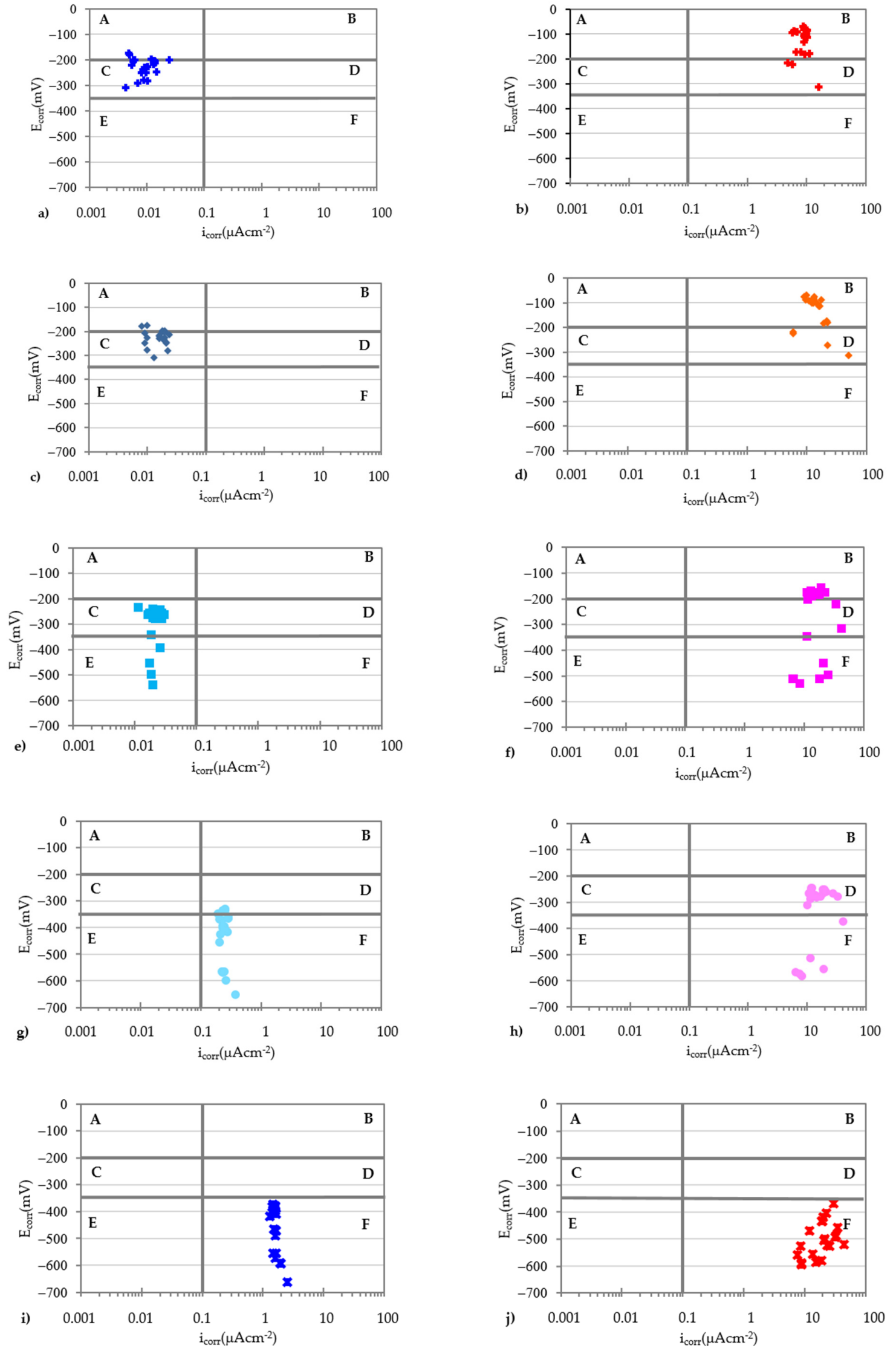

Figure 9. Cont. 

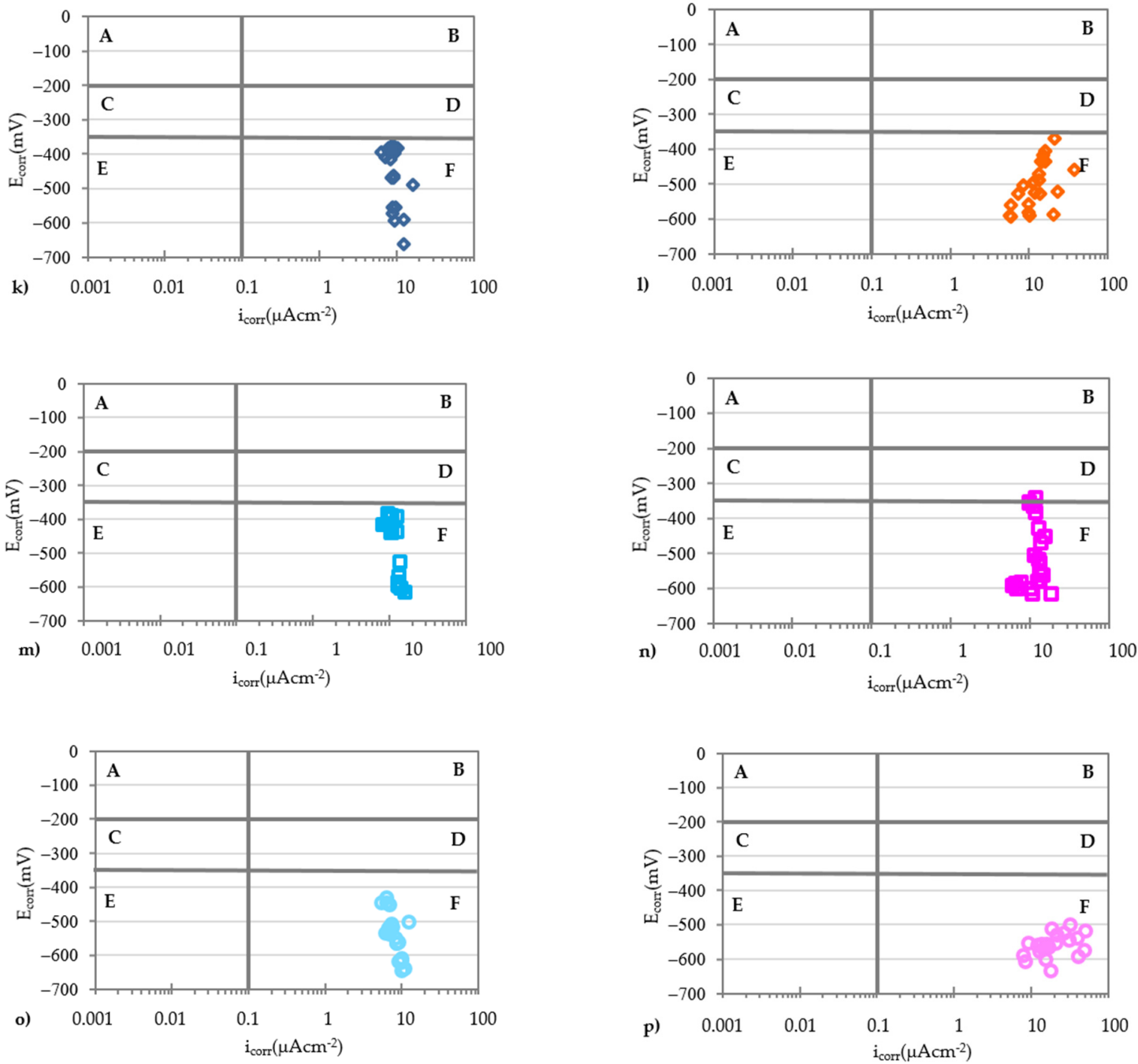

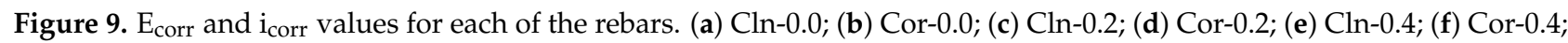
(g) Cln-0.6; (h) Cor-0.6; (i) Cln-0.8; (j) Cor-0.8; (k) Cln-1.0; (1) Cor-1.0; (m) Cln-1.5; (n) Cor-1.5; (o) Cln-2.0; (p) Cor-2.0.

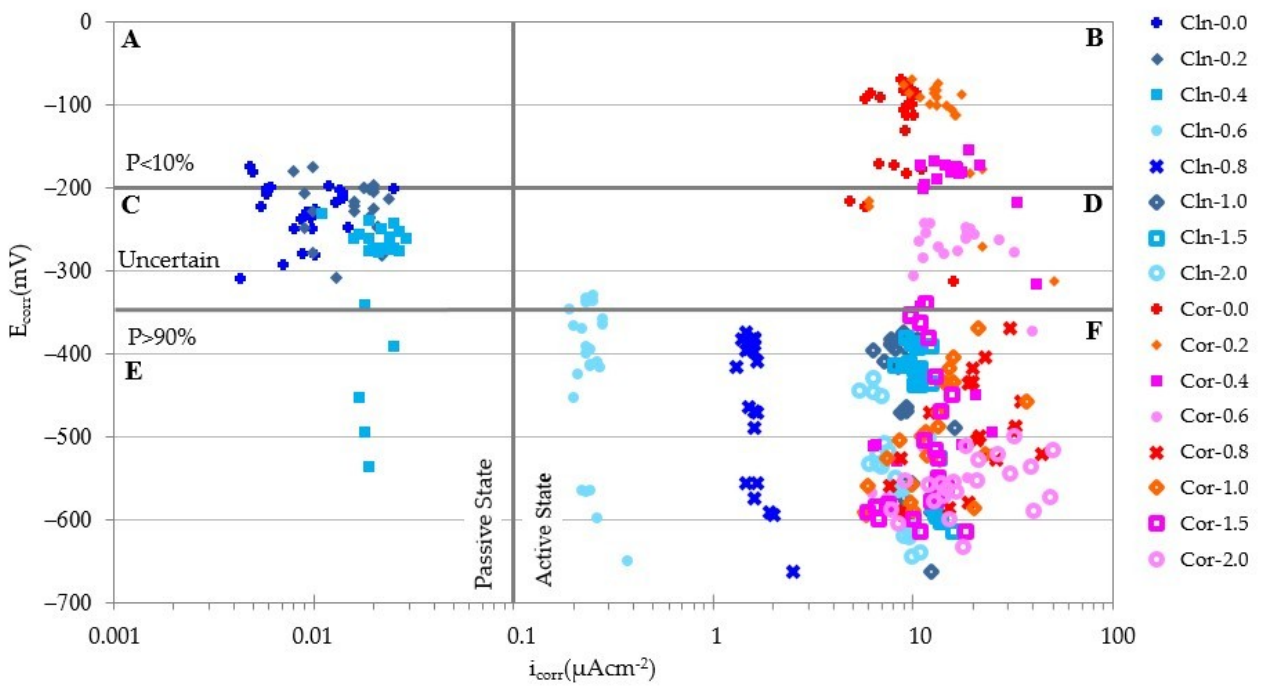

Figure 10. $\mathrm{E}_{\text {corr }}$ and $\mathrm{i}_{\text {corr }}$ values for all rebars. 


\section{Conclusions}

Previously corroded reinforcing steel bars have been soaked in mortar samples with varying contents of $\mathrm{Cl}$ - in two different states: previously pickled and with the corrosion products. They have been kept for 250 days in a humid chamber, and $\mathrm{E}_{\text {corr }}$ and $\mathrm{i}_{\text {corr }}$ have been measured and obtained with the following conclusions being drawn:

- All the rebars that have kept the corrosion products showed a very high $\mathrm{i}_{\text {corr }}$ and a similar value, approximately $10 \mu \mathrm{A} / \mathrm{cm}^{2}$, regardless of the number of chlorides present in the specimen.

- Clean rebars (CLN) embedded in specimens with $0.6 \mathrm{Cl}^{-}$remain with uncertain $\mathrm{i}_{\text {corr }}$ (values between 0.1 and $1.0 \mu \mathrm{A} / \mathrm{cm}^{2}$ ).

- The values of the $\mathrm{E}_{\mathrm{corr}}$ measurement depended more on the amount of $\mathrm{Cl}^{-}$present in the specimen than on the passive or active state of the rebars.

- Only the predictions of the $\mathrm{E}_{\mathrm{corr}}$ and $\mathrm{i}_{\text {corr }}$ coincided in bars embedded in specimens with at least a $0.8 \% \mathrm{Cl}^{-}$by weight cement ratio, regardless of whether the rebar is clean or maintains the corrosion products.

- The low correlation of the results obtained in the $\mathrm{E}_{\text {corr }}$ and $\mathrm{i}_{\text {corr }}$ in different situations, makes it impossible to predict the passive or active state of the steel solely based on $\mathrm{E}_{\text {corr }}$ measurements.

- To repair a concrete structure corroded by the effect of chloride ions, the concrete that surrounds the rebars must be removed so that all the corrosion products generated on the surface of the rebars can be eliminated. If the complete removal of the corrosion products is not achieved, even if a repair mortar is placed on it, the rebars will remain in active state.

Author Contributions: Conceptualization, A.C. and M.d.l.N.G.; methodology, A.C. and M.I.P.; software, F.I.O.; validation, M.d.I.N.G. and M.I.P.; formal analysis, M.I.P. and F.I.O.; investigation, A.C.; resources, M.d.I.N.G.; data curation, F.I.O.; writing—original draft preparation, A.C.; writing -review and editing, M.I.P.; visualization, M.d.l.N.G.; supervision, A.C.; project administration, M.d.l.N.G. All authors have read and agreed to the published version of the manuscript.

Funding: This research received no external funding.

Institutional Review Board Statement: Not applicable.

Informed Consent Statement: Not applicable.

Data Availability Statement: Data available on request.

Conflicts of Interest: The authors declare no conflict of interest.

\section{References}

1. Slater, J.E. Corrosion of Metals in Association with Concrete; ASTM-STP: Philadelphia, PA, USA, 1983; Volume 818.

2. Flis, J.; Pickering, H.W.; Osseo-Asare, K. Interpretation of Impedance Data for Reinforcing Steel in Alcaline Solutions Containing Chlorides and Acetates. Electrochim. Acta 1998, 43, 1921-1929. [CrossRef]

3. Page, C.L. Mechanism of corrosion protection in reinforced concrete marine structures. Nature 1975, 258, 514-515. [CrossRef]

4. Hope, B.B.; Page, J.A.; Ip, A.K.C. Corrosion rates of steel in concrete. Cem. Concr. Res. 1986, 16, 771-781. [CrossRef]

5. Federal Highway Administration. 6 FHWA Research Engineer Wins Arthur S. Flemming Award Promoted Advanced Bridge Inspection Technologies; Federal Highway Administration: Washington, DC, USA, 2001.

6. $\quad$ BRE Group. Report No 4; Building Research Establishment Ltd.: Watford, UK, 2001.

7. Angst, U.M. Challenges and opportunities in corrosion of steel in concrete. Mater. Struct. 2018, 51, 4. [CrossRef]

8. Pillai, R.G.; Trejo, D. Surface condition effects on critical chloride threshold of steel reinforcement. ACI Mater. J. 2005, 102, $103-109$.

9. Gancedo, J.R.; Alonso, C.; Andrade, C.; Gracia, M. AES study of the passive layer formed on iron in saturated $\mathrm{Ca}(\mathrm{OH})_{2}$ solutions. Corrosion 1989, 45, 976-977. [CrossRef]

10. Torbati-Sarraf, H.; Poursaee, A. Corrosion of coupled steel with different microstructures in concrete environment. Constr. Build. Mater. 2018, 167, 680-687. [CrossRef]

11. González, J.A.; Otero, E.; Feliú, S.; Bautista, A.; Ramírez, E.; Rodríguez, P.; López, W. Some considerations on the effect of chloride ion son the corrosion of Steel reinforcements embedded in concrete structures. Mag. Concr. Res. 1998, 50, 189-199. [CrossRef] 
12. Galán, I.; Andrade, C.; Castellote, M. Natural and accelerated $\mathrm{CO}_{2}$ binding Kinetics in cement paste at different relative humidity. Cem. Concr. Res. 2013, 49, 21-28. [CrossRef]

13. Revert, A.B.; De Weerdt, K.; Hornbstel, K.; Geiker, M.R. Carbonation-induced corrosion: Investigation of the corrosion onset. Constr. Build. Mater. 2018, 162, 847-856. [CrossRef]

14. Piqueras, M.A.; Company, R.; Jódar, L. Numerical analysis and computing of free boundary problems for concrete carbonation chemical corrosion. J. Comput. Appl. 2018, 336, 297-316. [CrossRef]

15. Tristan Senga Kiesse, T.S.; Bonnet, S.; Amiri, O.; Ventura, A. Analysis of corrosion risk due to chloride diffusion for concrete structures in marine environment. Mar. Struct. 2020, 73, 102804. [CrossRef]

16. Li, C.; Chen, Q.; Wang, R.; Wu, M.; Jiang, Z. Corrosion assessment of reinforced concrete structures exposed to chloride environments in underground tunnels: Theoretical insights and practical data interpretations. Cem. Concr. Compos. 2020, 112, 103652. [CrossRef]

17. Angst, U.; Elsener, B.; Larsen, C.K.; Vennesland, O. Critical chloride content in reinforced concrete-A review. Cem. Concr. Res. 2009, 39, 1122-1138. [CrossRef]

18. Wang, Y.; Liu, C.; Wang, Y.; Li, Q.; Liu, Z. Investigation on chloride threshold for reinforced concrete by a test method combining ANDT and ACMT. Constr. Build. Mater. 2019, 214, 158-168. [CrossRef]

19. Page, C.L.; Lambert, P.; Vassie, P.R.W. Investigation of reinforcement corrosion: 1. The pore electrolyte phase in chloridecontaminated concrete. Mater. Struct. 1991, 24, 243-252. [CrossRef]

20. Lambert, P.; Page, C.L.; Vassie, P.R.W. Investigation of reinforcement corrosion: 2. Electrochemical monitoring of steel in chloride-contaminated concrete. Mater. Struct. 1991, 24, 351-358. [CrossRef]

21. Oh, B.H.; Jang, S.Y.; Shin, Y.S. Experimental investigation of the threshold chloride concentration for corrosion initiation in reinforced concrete structures. Mag. Concr. Res. 2003, 55, 117-124. [CrossRef]

22. Kayyali, O.A.; Haque, M.N. The ratio of $\mathrm{Cl}^{-} / \mathrm{OH}^{-}$in chloride contaminated concrete. A most important criterion. Mag. Concr. Res. 1995, 47, 235-242. [CrossRef]

23. Ann, K.T.; Song, H.W. Chloride threshold level for corrosion of steel in concrete. Corros. Sci. 2007, 49, 4113-4133. [CrossRef]

24. Haussman, D.A. Steel corrosion in concrete; How does it occur? Mater. Prot. 1967, 6, 19-23.

25. Rossi, E.; Polder, R.; Copuroglu, O.; Nigland, T.; Savija, B. The influence of defects at the steel/concrete interface for chlorideinduced pitting corrosion of naturally deteriorated 20 years old specimens studied through X-ray Computed Tomography. Constr. Build. Mater. 2020, 235, 117474. [CrossRef]

26. Shi, J.; Ming, J. Influence of defects at the steel-mortar interface on the corrosion behavior of steel. Constr. Build. Mater. 2017, 136, 118-125. [CrossRef]

27. Soylev, T.A.; Francois, R. Quality of steel-concrete interface and corrosion of reinforcing steel. Cem. Concr. Res. 2003, 33, 1407-1415. [CrossRef]

28. Mohammed, T.U.; Otsuki, N.; Hamada, H.; Yamaji, T. Chloride-induced corrosion of steel bars in concrete with presence of gap at steel-concrete interface. ACI Mater. J. 2002, 99, 149-156.

29. Kenny, A.; Katz, A. Steel-concrete interface influence on chloride threshold for corrosion-Empirical reinforcement to theory. Constr. Build. Mater. 2020, 244, 118376. [CrossRef]

30. Alhozaimy, A.; Hussain, R.R.; Al-Negheimish, A. Electro-chemical investigation for the effect of rebar source and surface condition on the corrosion rate of reinforced concrete structures under varying corrosive environments. Constr. Build. Mater. 2020, 244, 118317. [CrossRef]

31. Duracrete. General Guidelines for Durability Design and Redesign; CUR: Gouda, Belgium, 2000.

32. de Fomento, M. Instrucción de Hormigón Estructural EHE-08; Madrid, Spain, 2008. Available online: https://www.mitma.gob.es/ recursos_mfom/1820100.pdf (accessed on 20 October 2021).

33. American Concrete Institute. ACI 318-19 Building Code Requirements for Structural Concrete and Commentary; American Concrete Institute: Farmington Hills, MI, USA, 2019.

34. Ožbolt, J.; Balabanic, G.; Kušter, M. 3D Numerical modelling of steel corrosion in concrete structures. Corros. Sci. 2011, 53, 4166-4177. [CrossRef]

35. Chauhan, A.; Sharma, U.K. Crack propagation in reinforced concrete exposed to non-uniform corrosion under real climate. Eng. Fract. Mech. 2021, 248, 107719. [CrossRef]

36. Chen, J.; Zhang, W.; Tang, Z.; Huang, Q. Experimental and numerical investigation of chloride-induced reinforcement corrosion and mortar cover cracking. Cem. Concr. Compos. 2020, 111, 103620. [CrossRef]

37. Xu, F.; Xiao, Y.; Wang, S.; Li, W.; Liu, W.; Du, D. Numerical model for corrosion rate of steel reinforcement in cracked reinforced concrete structure. Constr. Build. Mater. 2018, 180, 55-67. [CrossRef]

38. Fekak, F.E.; Garibaldi, L.; Elkhalfi, A.; Alami, E.E. A numerical study of pitting corrosion in reinforced concrete structures. J. Build. Eng. 2021, 43, 102789.

39. ASTM C876-09 Standard. Standard Test Method for Half-Cell Potentials of Uncoated Reinforcing Steel in Concrete; ASTM International: West Conshohocken, PA, USA, 2009. [CrossRef]

40. Videm, K. Corrosion of Reinforcement in Concrete. Monitoring, Prevention and Rehabilitation. (EFC 25); RC Press: London, UK, 1998; Chapter 10, pp. 104-121. 
41. Ismail, M.; Ohtsu, M. Corrosion rate of ordinary and high-performance concrete subjected to chloride attack by AC impedance spectroscopy. Constr. Build. Mater. 2006, 20, 458-469. [CrossRef]

42. Reou, J.S.; Ann, K.Y. Electrochemical assessment on the corrosion risk of steel embedment in OPC concrete depending on the corrosion detection techniques. Mater. Chem. Phys. 2009, 113, 78-84. [CrossRef]

43. Andrade, C.; Keddam, M.; Nóvoa, X.R.; Pérez, M.C.; Rangel, C.M.; Takenouti, H. Electrochemical behavior of steel rebars in concrete: Influence of environmental factors and cement chemistry. Electrochim. Acta 2001, 46, 3905-3912. [CrossRef]

44. González, J.A.; Miranda, J.M.; Feliú, S. Considerations on reproducibility of potential and corrosion rate measurements in reinforced concrete. Corros. Sci. 2004, 46, 2467-2485. [CrossRef]

45. Sagües, A. Corrosion Measurement Techniques for Steel in Concrete. In Corrosion-National Association of Corrosion Engineers Annual Conference; NACE: Houston, TX, USA, 1993.

46. Ministerio de la Presidencia. RC-16, Instrucción para la Recepción de Cementos; Boletín Oficial del Estado: Madrid, Spain, 2016.

47. Stern, M.; Geary, A.L. Electrochemical polarization I. A theoretical analysis of the shape of the polarization curves. J. Electrochem. Soc. 1957, 104, 56-63. [CrossRef]

48. Bastidas, D.M.; González, J.A.; Feliú, S.; Cobo, A.; Miranda, J.M. A quantitative study of concrete-embedded steel corrosion using potentiostatic pulses. Corrosion 2007, 63, 1094-1100. [CrossRef]

49. Prieto, M.I.; Cobo, A.; Rodríguez, A.; González, M.N. The efficiency of surface-applied corrosion inhibitors as a method for the repassivation of corroded reinforcement bars embedded in ladle furnace slag mortars. Constr. Build. Mater. 2014, 54, 70-77. [CrossRef]

50. Browne, R.D.; Geoghegan, M.P.; Baker, A.F. Corrosion Monitoring of Steel in Concrete. In Corrosion of Reinforcement in Concrete Construction; Crane, A.P., Ed.; Ellis Horwood Ltd.: Chichester, UK, 1983; Chapter 13; pp. 193-222.

51. Elsener, B.; Andrade, C.; Gulikers, J.; Polder, R.; Raupach, M. Half-cell potential measurements—Potential mapping on reinforced concrete structures. Mater. Struct. 2003, 36, 1-11. [CrossRef]

52. Andrade, C.; Alonso, C. Test methods for on-site corrosion rate measurements of steel reinforcement in concrete by means of the polarization resistance method. Mater. Struct. 2004, 37, 623-643. [CrossRef]

53. Network, D. Manual de Inspección, Evaluación y Diagnóstico de Corrosión en Estructuras de Hormigón Armado; CYTED Programe: Rio de Janeiro, Brazil, 1998; ISBN 980-296-541-3.

54. Eurocode 2: Design of Concrete Structures-Part 1-1: General Rules and Rules for Buildings; CEN: Brussels, Belgium, 2004.

55. Prieto, M.I.; Cobo, A.; Rodríguez, A.; Calderón, V. Corrosion behavior of reinforcements bars embedded in mortar specimens containing ladle furnace slag in partial substitution of aggregate and cement. Constr. Build. Mater. 2013, 38, 188-194. [CrossRef]

56. Martinez, M.J.; Lopez, M.; Cantero, D.; Rodríguez, J. Influence of the previous state of corrosion of rebars in predicting the service life of reinforced concrete structures. Constr. Build. Mater. 2018, 188, 915-923. [CrossRef]

57. Miranda, J.M.; González, J.A.; Cobo, A.; Otero, E. Several question about electrochemical rehabilitation methods for reinforced concrete structures. Corros. Sci. 2006, 48, 2172-2188. [CrossRef]

58. Macdonald, D.D.; Qiu, J.; Zhu, Y.; Yang, J.; Engelhardt, G.R.; Sagüés, A. Corrosion of rebar in concrete. Part I: Calculation of the corrosion potential in the passive state. Corros. Sci. 2020, 177, 109018. [CrossRef] 